\title{
Revision of the lichen genus Myelochroa (Ascomycotina: Parmeliaceae) in Korea
}

\author{
Kwang Hee Moon ${ }^{1, *}$, Chorong Ahn ${ }^{1}$ and Hiroyuki Kashiwadani ${ }^{2}$ \\ ${ }^{1}$ National Institute of Biological Resources, Environmental Research Complex, Seo-gu, Incheon 404-708, KOREA \\ ${ }^{2}$ Department of Botany, National Museum Nature and Science, 4-1-1 Amakubo, Tsukuba 305-0005, JAPAN \\ *Correspondent: lichenkr@korea.kr
}

\begin{abstract}
Korean species of the genus Myelochroa are revised taxonomically and the following eight species are recognized: $M$. aurulenta (Tuck.) Elix \& Hale, M. entotheiochroa (Hue) Elix \& Hale, M. galbina (Ach.) Elix \& Hale, M. hayachinensis (Kurok.) Elix \& Hale, M. irrugans (Nyl.) Elix \& Hale, M. leucotyliza (Nyl.) Elix \& Hale, M. metarevoluta (Asahina) Elix \& Hale and M. perisidians (Nyl.) Elix \& Hale. Myelochroa ibukiensis K.H. Moon et al. is reduced to a synonym for M. aurulenta. Myelochroa denegans (Nyl.) Elix \& Hale, M. indica (Hale) Elix \& Hale and M. xantholepis (Mont. \& Bosch) Elix \& Hale are excluded from the lichen of Korea. In addition, a key for the species of the Korean Myelochroa is provided.
\end{abstract}

Keywords: Korea, lichen, Myelochroa, taxonomy

(C) 2015 National Institute of Biological Resources

DOI:10.12651/JSR.2015.4.1.023

\section{INTRODUCTION}

The genus Myelochroa (Lichenized Ascomycetes, Lecanorales) is well-known foliose lichen widely distributed in eastern Asia and which comprises about 33 species in the world.

According to Kurokawa and Arakawa (1997), all species of the genus, excepting for $M$. indica (Hale) Elix \& Hale, produce secalonic acid A in the medulla of thalli and apothecia. From chemical characters, three groups were recognizable in the present genus, namely the $M$. galbina group, the $M$. aurulenta group and the $M$. immiscens group. Species of the M. galbina group (M. galbina, M. hayachienesis, M. metarevoluta and M. obsessa) are characterized by production of galbinic acid and triterpenoids. It is noteworthy that the species of this group always form moniliform cells (Asahina, 1952) in the medulla. Species of the M. aurulenta group (M. aurulenta, $M$. entotheiochroa and M. irrugans; majority of the genus belong to the present group) produce triterpenoids but lack galbinic acid. They do not form moniliform cells in the medulla. Species of the M. immiscens group (M. immiscens and $M$. lindamanii) do not produce galbinic acid or triterpenoids and do not form monilioform cells. Species of the $M$. immiscens group are now treated under the genus Parmotrema.

In Korea, 13 species had been reported under Myelo- chroa until 1990 (Asahina, 1951; 1952; Kim, 1965; 1979; 1980; 1981; Park, 1976; Cho and Lee, 1980; Ban, 1983; Kim, 1983; Lee, 1987; Ri, 1988; Huneck et al., 1989; Park, 1990). Among them, several species have been synonymized as follows; $M$. coreana Y.S. Park with $M$. aurulenta (Tuck.) Elix \& Hale (Moon, 1999), M. rhytidodes (Hale) Elix \& Hale with $M$. entotheiochroa (Hue) Elix \& Hale and M. crassata (Hale) Elix \& Hale and $M$. subaurulenta (Nyl.) Elix \& Hale with M. irrugans (Nyl.) Elix \& Hale (Kurokawa and Arakawa, 1997). In addition, M. metarevoluta (Asahina) Elix \& Hale (Moon, 1999) and M. xantholepis (Mont. \& Bosch) Elix \& Hale (Jayalal et al., 2012) were added. At this time, therefore, 11 species have been known from Korea. In this study, Korean species of the genus have been revised based on modern taxonomic viewpoints using about 300 specimens preserved in NIBR, TNS, DUKE and KoLRI.

\section{Materials ANd Methods}

Morphological characters were studied by light and dissecting microscopes. Measurements of textures such as for thalli and spores were carried out in GAW solution mounts. Chemistry was studied by color test (Kurokawa, 1964) and by the thin-layer chromatography (Culberson, 1972) using the solvent B system. All specimens used in this study are deposited in the herbaria as cited herein. 


\section{Results AND Discussion}

Myelochroa aurulenta (Tuck.) Elix \& Hale, Mycotaxon 29: 240, 1987.

Basinonym: Parmelia aurulenta Tuck., Amer. J. Sci. Arts, Ser. 2 25: 424, 1858. Type collection: Harpers Ferry, Virginia, U.S.A., Tuckerman (lectotype in FH, Tuckerman Herb.!).

Parmelina aurulenta (Tuck.) Hale, Smiths. Contr. Bot. 33: 19, 1976.

Myelochroa coreana Y.S. Park, Bryologist 93: 132, 1990. Type collection: South Korea. Kwangwon Province: Mt. Sorak National Park, elevation 1100 m, July 10, 1986, Y.S. Park 1837 (holotype in DUKE!).

Myelochroa ibukiensis K.H. Moon, Kashiw. \& Keis. Kobay., J. Jpn. Bot. 88: 140, 2013. Type collection: JAPAN. Prov. Ohmi (Shiga Pref.): Ibuki Shrine, Ibuki, Maibara City. On bark of Zelkova serrata, elevation about 180 m, November 16, 2012, H. Kashiwadani 50701 (holotype in TNS!).

For other synonyms, see Hale (1976) and Kurokawa and Arakawa (1997).

Chemistry. Race 1, atranorin, zeorin, leucotylic acid and its derivatives, and secalonic acid A. Race 2, atranorin, zeorin, leucotylin and its derivatives, and secalonic acid $\mathrm{A}$.

Myelochroa aurulenta is characterized by a foliose thallus with pustules or granular soredia and a yellow medulla containing secalonic acid A, zeorin, and leucotylic acid or leucotylin.

The present species is easily distinguished from allied species of the genus by the presence of soredia. Soralia are variable in shape, varying from pustules to farinose soredia. They are formed laminally and subterminally; laminal soralia are rounded and often diffusing, and subterminal soredia often inflated, forming capitate soralia.

Hale (1976) considered that Parmelina aurulenta (= Myelochroa aurulenta) produces leucotylic acid as the major substance. According to Kurokawa and Arakawa (1997), leucotylic acid was demonstrated in 24 of 25 specimens collected in Japan, while leucotylin was detected from only one specimen. The Korean materials show a similar tendency with leucotylic acid demonstrated in 40 of the 43 specimens and leucotylin detected in only three specimens; however, no morphological differences have been found between the two chemical races, and the chemical difference seems to have no taxonomic value.

Park (1990) described Myelochroa coreana Y.S. Park based on a specimen collected at Mt. Sorak, Korea. As discussed by Moon (1999), the holotype specimen preserved in DUKE shows typical morphological characters found in M. aurulenta. In addition, specimens examined by her include the two chemical variations shown above. Therefore, $M$. coreana is simply reduced to a synonym of $M$. aurulenta.

Moon et al. (2013) described Myelochroa ibukiensis K.H. Moon, Kashiw. \& K. Kobayashi based on a specimen collected at Ibuki, Maebara-city, Japan. They stressed the presence of red dots that appeared to be pigments of the medulla; however, detailed study of the holotype reveals that the red dots are derived from the juvenile colony of a parasitic fungus (Marchandiomyces corallines), which does not belong with the mycobiont of the holotype. All other morphological and chemical characters are those found in M. aurulenta. Thus, M. ibukiensis is reduced to a synonym of $M$. aurulenta.

In Korea, M. aurulenta has been reported as Parmelia aurulenta (Park, 1979; Lee, 1987; Ri and Hyun, 1988; Ri, 1988; 2000), Parmelina aurulenta (Hale, 1976), M. coreana (Park, 1990) and M. aurulenta (Park, 1990; Moon, 1997; 1999; Kashiwadani et al., 2002; Hur et al., 2004; Jayalal et al., 2012).

Myelochroa aurulenta is widely distributed in temperate and subtropical regions in the world excepting Europe, having been reported from Japan, eastern and southeastern Asia including Siberia, Korea, mainland China, Taiwan, Hong Kong, Pakistan, Nepal, India, Sri Lanka, Java, the Philippines, New Guinea, eastern Africa including Madagascar, Hawaii, Canada, the U. S. A., Mexico and South America (Hale, 1976) and Australia (Kurokawa and Arakawa, 1997). This species was also reported from Thailand (Moon et al., 2000), Fiji (Elix, 2001) and Turkey (Yazici et al., 2010).

Myelochroa aurulenta is apparently widely distributed throughout the Korean peninsula.

Representative specimens examined. Prov. Hamkyongnam, Pyong-yang, Forest Sung-ja, P. Chun (F. Den) (TNS). Prov. Gangwon (=Prov. Kangwon), Pyongchang-gun, Jinbu-myun, Mt. Ohdae, around Woljong temple, on Tsuga sp., elevation 670-690 m, October 8, 1995, K.H. Moon 1956 \& H. Kashiwadani (TNS); Injegun, Puk-myon, Mt. Sorak, around Peaktam temple, on bark of Prunus jamasakura, elevation 460-550 m, October 6, 1995, K.H. Moon 405 \& H. Kashiwadani (TNS). Prov. Gyongsangbuk, Yecheon-gun, Pungyang-myeon, Hyogal-ri, around Chungryoung Temple, on bark of Juniperus sp., elevation 145 m, May 3, 2009, K.H. Moon 10820 (NIBR); Gyeongju city, Jinhyeon-dong, around Bulguk temple, on bark of Zelkova serrata, elevation $230 \mathrm{~m}$, September 16, 2012, K.H. Moon 13463 (NIBR). Prov. Jeonllanam, Gohung-gun, Podu-myeon, Mt. Cheoundeung, St. Gumtap-gil, around Gumtap temple, on bark of Zelkova serrata, elevation 100 m, October 18, 2013, K.H. Moon 13877 (NIBR). Prov. Jeju (=Prov. Cheju), Che- 
ju-shi, Odung-dong, Kwanum temple, on bark of Prunus sp., elevation about 580 m, May 29, 2001, K.H. Moon 5928 (TNS).

Myelochroa entotheiochroa(Hue) Elix \& Hale, Mycotaxon 29: 240, 1987.

Basinonym: Parmelia entotheiochroa Hue, Nouv. Archiv. du Museum, ser. 4., 1: 161, 1899. Type collection: Hakodate, Japan, Faurie 104 pp. (lectotype PC, isotype in TNS!)

Parmelina entotheiochroa (Hue) Hale, Smiths. Contr. Bot. 33: 28, 1976.

Myelochroa rhytidodes (Hale) Elix \& Hale, Mycotaxon 29: 241, 1987. Type collection. Amagi Pass, Prov. Izu, Honshu, Japan, S. Kurokawa 58601 (holotype US; isotype TNS!, as Parmelina rhytidodes Hale).

For other synonyms, see Kurokawa and Arakawa (1997).

Chemistry. Race 1, atranorin, zeorin, leucotylic acid and its derivatives, and secalonic acid A. Race 2, atranorin, zeorin, leucotylin and its derivatives, and secalonic acid A.

This species is characterized by the lack of soredia, reticulate wrinkles often burst open along the ridges, and the very fragile upper cortex that is often flaked away to expose the medulla.

It is easily distinguished from allied species by the wrinkled and fragile thallus, which often exposes yellow or white patches of medulla. Ridges of wrinkles found on the thallus often burst open but never produce soredia or pustules.

Hale (1976) reported leucotylin as the major chemical substance of Myelochroa enthotheiohroa; however, in Korea, 13 of 20 specimens produced leucotylin while 7 produced leucotylic acid. A similar result was also reported from Japan (Kurokawa and Arakawa, 1997).

Myelochroa entotheiochroa is one of the commonest foliose species in lowland Korea. In Korea, M. entotheiochroa has been reported as Parmelia entotheiochroa (Asahina, 1951; 1952; Kim, 1965; 1979; 1980; 1981; Park, 1976; Cho and Lee, 1980; Lee, 1987; Ri, 1988; Huneck et al., 1989), as Parmelina entotheiochroa (Hale, 1976), as M. entotheiochroa (Park, 1990; Moon, 1997; Kashiwadani et al., 2002; Hur et al., 2004; Jayalal et al., 2012) and as M. rhytidodes (Park, 1990). One specimen reported as $M$. xantholepis by Jayalal et al. (2012) is identified as $M$. entotheiochroa.

Outside of Korea, M. entotheiochroa has been reported from Japan, Nepal and Thailand (Kurokawa and Arakawa, 1997). Recently it was reported from India and Sri Lanka (Jayalal et al., 2012). It is apparently very common throughout the lowlands of the Korean peninsula.
Representative specimens examined. Prov. Gangwon (=Prov. Kangwon), Hoiyang-gun, Paekam, August 1, 1934, F. Fujikawa; Sokcho city, Mt. Sorak, E slope of Mt. Daechongbong, on bark of Abies mariesii, elevation about 1480-1708 m, July 17, 1996, Y. Ohmura 2325 \& K.H. Moon (TNS); Pyeongchang-gun, Jinbu-myeon, Mapyeong-ri, Mt. Odae, beside Ohdae stream, on rocks, elevation 386 m, June 18, 2009, K.H. Moon 11009 (NIBR); Prov. Chungcheongbuk, Danyang-gun, Mt. Sobaek, on bark, elevation 647 m, October 2, 2003, J.S. Hur 030725 (KoLRI no. 000522, as M. cf. xantholepis); Prov. Gyongsangbuk, Cheongdo-gun, Unmun-myeon, Sinwon-ri, Mt. Gaji National Park, en route from Unmun Temple to Sari Temple, on rocks, elevation 220-400 m, March 26, 2009, K.H. Moon 10790 (NIBR); Prov. Gyongsangnam, Sancheong-gun, Sicheon-myeon, Jungsan-ri, Mt. Jiri, en route from Rotary hut to Mt. Cheonwang, elevation 1600 m, on bark, August 11, 2006, K.H. Moon 9004 (NIBR); Prov. Jeollanam, Goheung-gun, Geumsan-myeon, Sinchon-ri, Island Geogeum-do, seaside, elevation $9 \mathrm{~m}$, on rock with mosses, October 19, 2013, K.H. Moon 13949 (NIBR); Prov. Jeju (=Prov. Cheju), Cheju-shi, Odungdong, Kwanum temple, on bark of Prunus sp., elevation about 580 m, May 29, 2001, K.H. Moon 5927 (TNS); Cheju-shi, Jocheon-eup, Seonheul-ri, around pond Seonheul, on rocks (lava), elevation $180 \mathrm{~m}$, May 24, 2012, K.H. Moon 13027 (NIBR).

Myelochroa galbina (Ach.) Elix \& Hale, Mycotaxon 29: 240, 1987.

Basinonym: Parmelia galbina Ach., Syn. meth. lich.: 195, 1814. Type collection: North America (Pennsylvania?), Muhlenberg (lectotype in H, Acharius Herb.!).

For other synonyms, see Hale (1976) and Kurokawa and Arakawa (1997).

Chemistry. Atranorin, galbinic acid, zeorin, leucotylin and its derivatives, salazinic acid and secalonic acid A.

Myelochroa galbina is easily distinguished from other species of the genus by the thallus without asexual propagules, the $\mathrm{P}+$ reaction of the medulla, the presence of galbinic acid and the formation of moniliform cells in the medulla.

Hale (1976) reported the occurrence of leucotylin in this species. Kurokawa and Arakawa (1997) found irregular occurrence of this substance for Japanese specimens; instead of leucotylin, they demonstrated leucotylic acid in 11 of 20 Japanese specimens. In contrast, Korean material always produces leucotylin.

In Korea, M. galbina has been reported as Parmelia galbina (Lee, 1987) or M. galbina (Park, 1990; Moon, 1999; Kashiwadani et al., 2002; Jayalal et al., 2012).

Myelochroa galbina has a disjunctive distribution in eastern Asia and eastern North America (Kurokawa, 1972; 
Moon, 1999). In Asia, it has been reported from southern China, Taiwan and Nepal (Kurokawa and Arakawa, 1997).

Myelochroa galbina seems to be rather rare in Korea, where it has been collected in Gangwon (Moon, 1999) and Jeju (Kashiwadani et al., 2002) provinces and on Mt. Jiri (Lee, 1987; Jayalal et al., 2012).

Specimens examined. Prov. Gangwon (=Prov. Kangwon), Inje-gun, Mt. Sorak, Paektam temple area, on bark along stream, elevation about $420 \mathrm{~m}$, October 6, 1995, K.H. Moon 390 \& H. Kashiwadani (TNS); Inje-gun, Mt. Sorak, Paektam temple area, on bark along stream, elevation about 430 m, October 21, 2006, K.H. Moon 9156 (NIBR). Prov. Jeju (=Prov. Cheju) Mt. Halla, en route from Witsae Oreum Shelter to Eorimok, on bark of Carpinus sp., elevation about 1000 m, May 24, 2001, K.H. Moon 5823 (TNS); Namcheju-gun, Namwon-up, Mt. Halla, along trail of Songpanak route to the summit, on decayed wood, elevation about 900 m, May 28, 2001, K.H. Moon 5920 (TNS).

Myelochroa hayachinensis (Kurok.) Elix \& Hale, Mycotaxon 29: 240, 1987.

Basinonym: Parmelia hyachinensis Kurok., J. Jpn. Bot. 43: 350, 1968. Type collection: Japan. Honshu. Prov. Rikuchu: Kadomaguchi, Mt. Hayachine. Elevation about 970 m, July 25, 1967. S. Kurokawa 67081 (holotype TNS!).

For other synonyms, Kurokawa and Arakawa (1997).

Chemistry. Atranorin, galbinic acid, zeorin, leucotylin and its derivatives, salazinic acid and secalonic acid A.

Myelochroa hayachinensis resembles M. leucotyliza in having pustules on the thallus; however, it can be distinguished from the latter by producing galbinic acid and having moniliform cells in the medulla. As pointed out by Kurokawa (1968), this species is the pustulate morph of M. galbina.

Myelochroa hayachinensis has been reported only from Korea and Japan. It has been considered to belong to the Koreo-Japanese element as reported by Moon (1999).

In Korea, M. hayachinensis was first reported from Mt. Halla in Jeju Island by Park (1990). It has been reported from only three localities in Korea; the other two being Mt. Pukhan, Seoul (Moon, 1998) and Mt. Backwoon (Jayalal et al., 2012).

Specimens examined. Seoul, Songbuk-gu, Mt. Pukhansan, on bark of Quercus mongolica along Chongnung stream, elevation about 240 m, August 24, 1997, K.H. Moon 1672 (TNS); Prov. Gyonggy (=Prov. Kyonggi), Koyang city, Mt. Pukhan-san, around Wonhyo temple, on bark of Quercus serrata, elevation about $250 \mathrm{~m}$, July
24, 1997, K.H. Moon 2453 (TNS). Prov. Gyongsangnam, Milyang city, Sannae-myeon, Samyang-ri, Mt. Gaji, Route Ocheonpyeong Rock, on rocks, elevation about 310 m, September 8, 2009, K.H. Moon 11315 (NIBR). Prov. Jeollanam, Gohung-gun, Podu-myeon, Namseongri, en route from Mabok-sa temple to summit area, on rock with mosses, elevation about $200 \mathrm{~m}$, October 20, 2013, K.H. Moon 13946 (NIBR). Prov. Jeju (=Prov. Cheju), Namcheju-gun, Namwon-up, Mt. Halla, along trail of Songpanak route to the summit, on bark of Quercus sp., elevation about 900 m, May 28, 2001, H. Kashiwadani 43721 (TNS).

Myelochroa irrugans (Nyl.) Elix \& Hale, Mycotaxon 29: 241, 1987.

Basinonym: Parmelia irrugans Nyl., Lich. Japon.: 26, 1890. Type collection. Japan, Umagayeshi, Mt. Fuji, E. Almquist (lectotype in H; Nylander Herb. 35551!).

Parmelia subaurulenta Nyl., Flora 68: 606, 1885-Myelochroa subaurulenta (Nyl.) Elix \& Hale, Mycotaxon 29: 241, 1987. Type collection. India, N.W. Himalays, Narkanda, Skoliczka (lectotype in H; Nylander Herb. 35672).

Parmelia homogenes Nyl., Flora 68: 607, 1885. Type collection. India, Hooker \& Thomson 1942 (lectotype in H; Nylander Herb. 35664).

Myelochroa crassata (Hale) Elix \& Hale, Mycotaxon 29: 240, 1987. Type collection. Japan, Prov. Kozuke, Mt. Amagi, S. Kurokawa 550466 (holotype US and isotype in TNS).

Parmelia denegans auct. non Nyl.: Cho SS and Lee YN, 1980.

Myelochroa xantholepis auct. non (Mont. \& Bosch) Elix \& Hale: Jayalal et al. 2012.

For other synonyms, Kurokawa and Arakawa (1997) and Hale (1976) under Parmelina irrugans and P. subaurulenta.

Chemistry. Race 1, atranorin, zeorin, leucotylic acid and its derivatives, and secalonic acid A. Race 2, atranorin, zeorin, leucotylin and its derivatives, and secalonic acid $\mathrm{A}$.

Myelochroa irrugans is characterized by the lobes loosely attached to the substrata, the absence of asexual propagules and the absence of galbinic acid. Morphologically this species very much resembles $M$. galbina, which differs by the production of galbinic and salazinic acids. In addition, it is rather loosely attached to the substrate, whereas $M$. galbina is always tightly attached.

In 2012, Jayalal et al. reported M. xantholepis (Mont. \& Bosch) Elix \& Hale from South Korea and stressed that their specimens have dimorphic lobes and a pale yellow medulla. Although the Korean specimens used by them have newly found small lobes (Fig. 1), these are not the same as those found in M. xantholepis, which has 


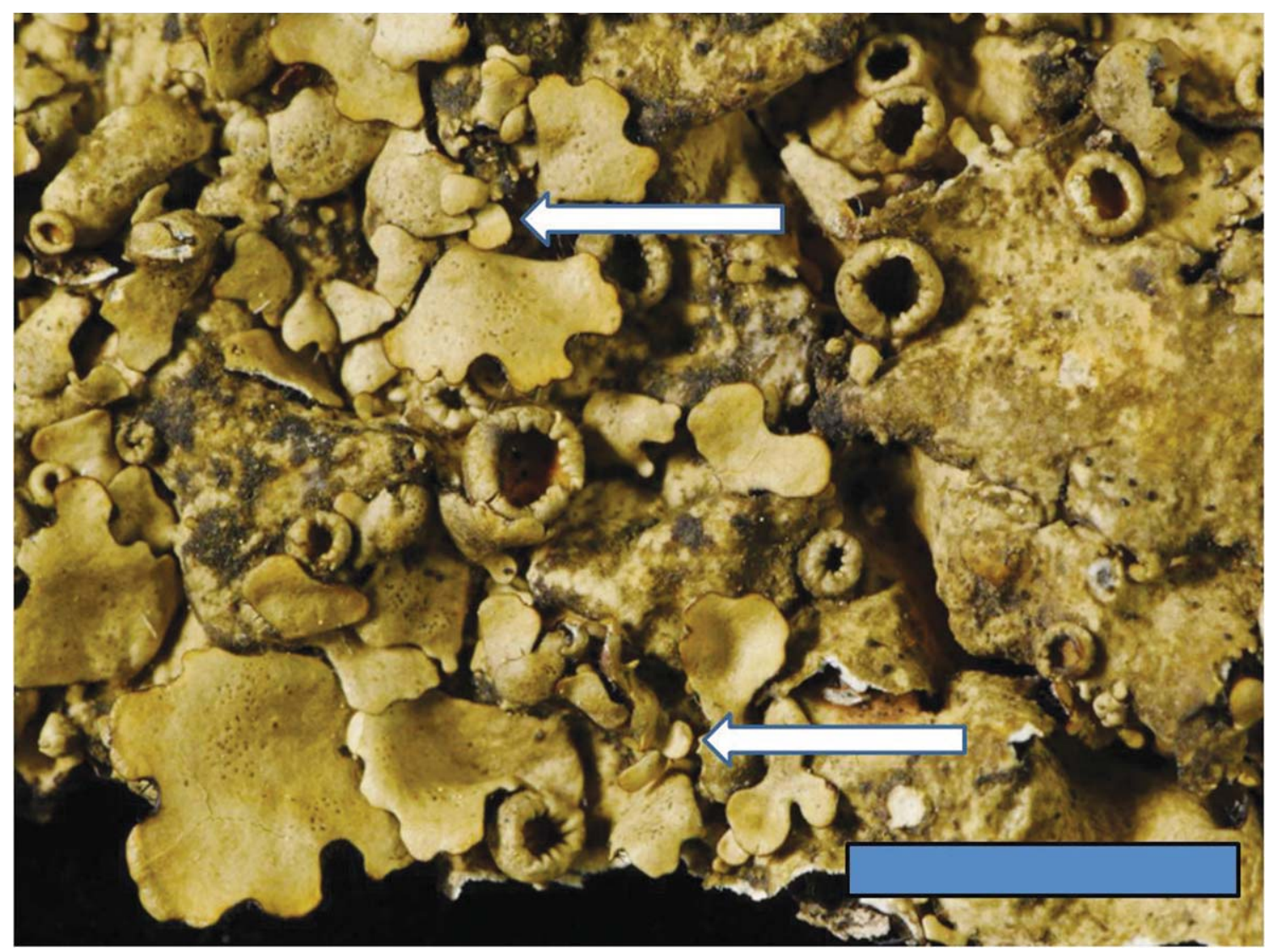

Fig. 1. Myelochroa irrugans (Nyl.) Elix \& Hale (reported as M. xantholepis (Mont. \& Bosch) Elix \& Hale by Jayalal et al. in 2012, J.S. Hur 070662 (KoLRI no. 007535), KoLRI), showing newly developed young lobes (arrows). Scale bar=5 mm.

dichotomously divided lobules (Fig. 2) toward the lobe margins (Hale, 1976). In addition, the yellow medulla of the Korean materials is different from the characteristic orange-yellow medulla observed in M. xantholepis (Hale, 1976). Therefore, these specimens should be simply identified with $M$. irrugans.

Cho and Lee (1980) reported the occurrence of Myelochroa denegans (Nyl.) Elix \& Hale under a name of Parmelia denegans. Although the specimen examined by them has disappeared and is unable to be traced, it is highly possible that this specimen could be identified with $M$. irrugans as they indicated the absence of soredia and isidia, and the presence of $\mathrm{K}+$ yellow medulla.

Myelochroa irrugans shows extensive variation in regard to thickness of the thallus, lobe width and size of mature apothecia. Among the specimens of this species, those with a narrow and thin thallus were once treated under Parmelia subaurulenta $(=M$. subaurulenta) and those with small apothecia as $P$. subaurulenta var. myriocarpa (Asahina, 1951); however, these morphological characters found in the present species have no taxonomic value for separating species as already discussed by Kurokawa and Arakawa (1997).
This species has two chemical races characterized by differences in terpenoides (the leucotylic acid containing race and the leucotylin containing race). Both races are commonly found throughout the Korean peninsula.

Myelochroa irrugans is one of the common species of Myelochroa in Korea. It has been reported from Korea as Parmelia irrugans (Lee, 1987), as Parmelia subaurulenta (Asahina, 1951; Kim, 1965; 1979; Park, 1976; Cho and Lee, 1980; Ban, 1983; Lee, 1987; Ri, 1988), as Parmelia homogenes (Kim, 1965; Cho and Lee, 1980; Ri, 1988), as M. crassata (Park, 1990), as M. subaurulenta (Park, 1990; Huneck et al., 1994) and as M. irrugans (Park, 1990; Moon, 1998; 1999; Kashiwadani et al., 2002; Hur et al., 2004; Jayalal et al., 2012).

This species seems to be endemic to eastern Asia, having been reported from China, India, Japan, Nepal, Sakhalin, Sri Lanka, Taiwan and Thailand (Kurokawa and Arakawa, 1997; Jayalal et al., 2012). In Korea, it grows on tree trunks and rocks including stone works and is found from lowlands to mountainous areas.

Representative specimens examined. Prov. Hamkyongnam, Shihung-gun, Hamjiwon, August 2, 1934, 


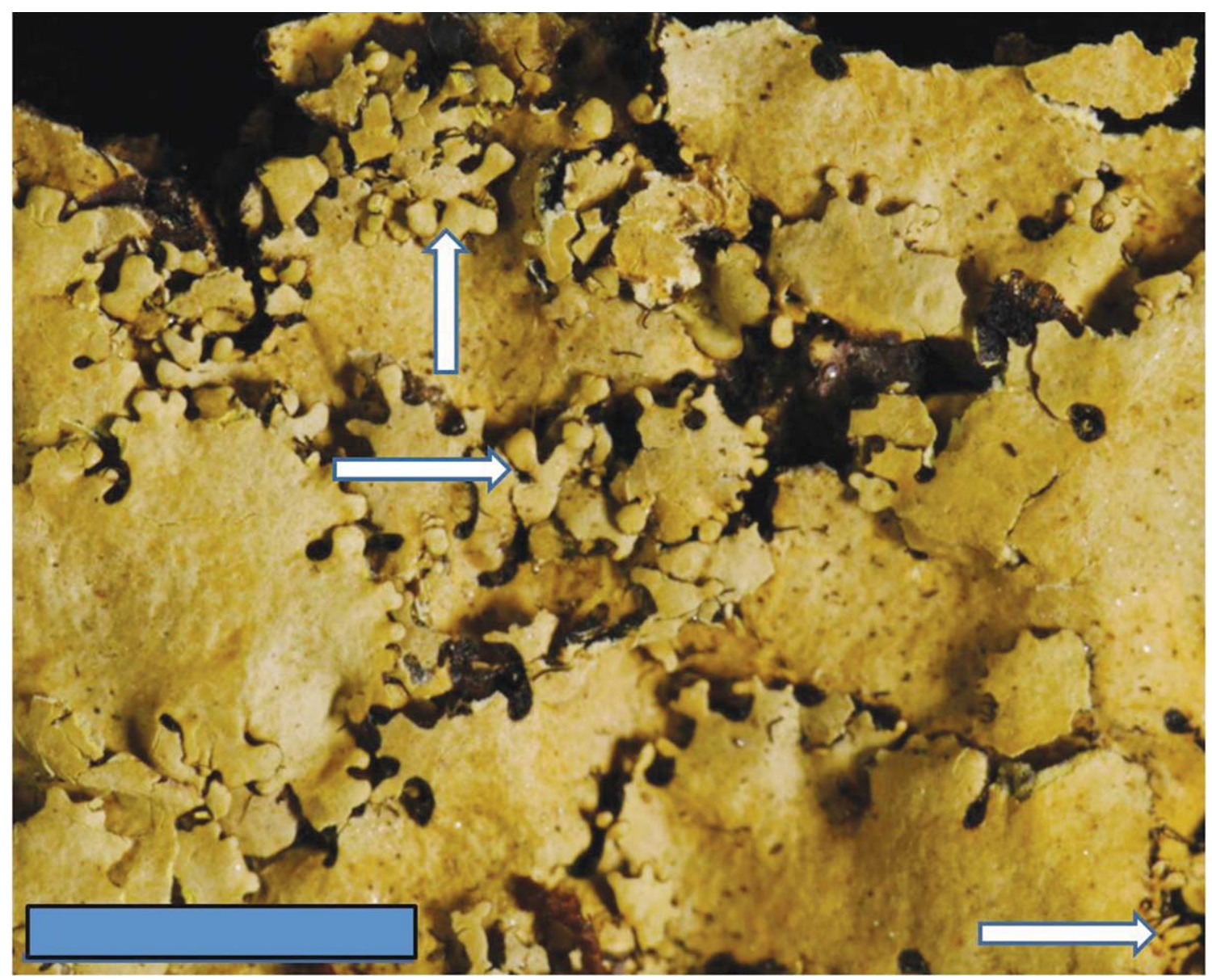

Fig. 2. Myelochroa xantholepis (Mont. \& Bosch) Elix \& Hale (collected from India and determined by S. Kurokawa, H. Hara s.n., TNS), showing dichotomously and irregularly divided lobules along the lobe margins (arrows). Scale bar $=5 \mathrm{~mm}$.

F. Fujikawa (TNS). Prov. Gangwon (=Prov. Kangwon), Tongchon-gun, eastern slope of Mt. Daimond, Outer Diamond (Ohikumgang), July 28, 1934, Y. Asahina (TNS); Pyongchang-gun, Jinbu-myun, Mt. Ohdae, around Woljong temple, on bark of Tsuga sp., elevation 670-690 m, October 8, 1995, K.H. Moon 1962 \& H. Kashiwadani (TNS); Hongcheon-gun, Nae-myeon, Myeonggae-ri, Mt. Ohdae, en route from Mt. Ohdae control office at Myounggyeri to Bukdae Temple, on bark of Quercus sp., elevation about 650 m, April 23, 2009, K.H. Moon 10961 (NIBR); Sokcho city, Mt. Sorak, en route from Mangyongdae to Mt. Daechongbong, on bark of Quercus crispula, elevation about 1000-1480 m, July 17, 1996, K.H. Moon 1076 \& H. Kashiwadani (TNS); Jeongseongun, Mt. Hambaek, on bark of Quercus sp., elevation 1401 m, June 19, 2007, J.S. Hur 070662 (KoLRI no. 007 535, as M. xantholepis). Seoul, Chongno-gu, Mt. Pukhansan, en route from Younhwa temple to Kumson temple, on rocks along stream, elevation about $285 \mathrm{~m}$, August 24, 1997, K.H. Moon 1680 (TNS). Incheon, Ongjin-gun, Bukdo-myeon, Jangbong-ri, on bark of Quercus acutis- sima, elevation about 10 m, April 20, 2013, K.H. Moon 13354 (NIBR). Prov. Chungcheongbuk, Danyang-gun, Mt. Sobaek, on bark, elevation 1322 m, April 25, 2007, J.S. Hur 070344 (KoLRI no. 007489, as M. cf. xantholepis); Danyang-gun, Mt. Sobaek, on bark of Quercus sp., elevation 1009 m, June 10, 2007, J.S. Hur 070412 (Ko LRI no. 007274, as M. cf. xantholepis). Prov. Gyongsangbuk, Pohang city, Nam-gu, Homigot-myeon, Gangsa-ri, on rocks, elevation about $20 \mathrm{~m}$, September 15, 2012, K.H. Moon 13442 (NIBR); Ulleung-gun, Ulleungeup, Dodong-ri, Haengnam walking track along east coast, on rocks, elevation about $5 \mathrm{~m}$, June 28,2012 (NIBR). Prov. Gyongsangnam, Geoje city, Jangseungpo-dong, on rocks, elevation about $50 \mathrm{~m}$, September 12, 2012, K.H. Moon 13368 (NIBR). Prov. Jeonllanam, Yeosu city, Geomun-do, on rock, elevation $61 \mathrm{~m}$, March 24, 2007, J.S. Hur 070150 (KoLRI no. 007137, as M. cf. xantholepis); Gohung-gun, Podu-myeon, Namseong-ri, around Geumtap-sa temple, on rocks, elevation about 100 m, October 18, 2013, K.H. Moon 13867 (NIBR); Sinan-gun, Heuksan-myeon, Jin-ri, Is. Heuksan en route 
from Ye-ri to Jin-ri, on rocks, elevation about $4 \mathrm{~m}$, July 29, 2008, K.H. Moon 10560 (NIBR). Prov. Jeju (=Prov. Cheju), Mt. Halla, en route from Youngshil Rest Area to Witsae Oreum Shelter, on bark of Quercus sp., elevation 1280-1650 m, May 24, 2001, K.H. Moon 5934 (TNS); Jeju city, Jocheon-eup, Seonheul-ri, around Seonheul pond, on bark of Prunus sp., elevation about $180 \mathrm{~m}$, May 24, 2012, K.H. Moon 13025 (NIBR).

Myelochroa leucotyliza (Nyl.) Elix \& Hale, Mycotaxon 29: 241, 1987.

Basinonym: Parmelia leucotyliza Nyl., Lich. Japon.: 27, 1890. Type collection. Japan, Rokosan, E. Almquist s. n. (lectotype in H; Nylander Herb. 35196!).

For other synonyms, see Hale (1976).

Chemistry. Atranorin, zeorin, leucotylin and its derivatives, and secalonic acid $\mathrm{A}$.

Myelochroa leucotyliza is characterized by the pustulate lobes forming granular soredia, the absence of moniliform cells in the medulla and the lack of galbinic acid. It resembles $M$. aurulenta, which differs in having farinose soredia. Externally it also resembles M. hayachinensis, but it is easily distinguished from the latter by the absence of galbinic acid.

All specimens of this species collected in Korea (NIBR and TNS) always contain leucotylin and lack leucotylic acid as confirmed by Japanese material (Kurokawa and Arakawa, 1997).

Myelochroa leucotyliza has been reported from Japan, Malaysia, China and Nepal (Kurokawa and Arakawa, 1997). It is one of the common foliose lichen in Korea. It has been reported from Korea (Park, 1990; Moon, 1998; 1999; Kashiwadani et al., 2002; Jayalal et al., 2012; and as the Parmelia leucotyliza by Lee, 1987).

Representative specimens examined. Prov. Gangwon (=Prov. Kangwon), Inje-gun, Mt. Sorak, around Paektam temple, on rock, elevation about 460-550 m. July 17, 1996, K.H. Moon 699 \& H. Kashiwadani (TNS); Hongcheon-gun, Nae-myeon, Myeonggae-ri, Mt. Ohdae, en route from Mt. Ohdae control office at Myounggyeri to Bukdae Temple, on bark of Quercus sp., elevation about 830 m, April 23, 2009, K.H. Moon 10902 (NIBR). Seoul, Kangbuk-gu, Mt. Pukhan-san, en route from Paegundae ticket office to Wimun via Kaltak pass, on bark of Quercus mongolica, elevation about 525 m, August 24, 1997, H. Kashiwadani 40399 (TNS). Prov. Gyongsangbuk, Cheongsong-gun, Budong-myeon, Sangui-ri, Mt. Juwang, en route from Daegeon temple to Mt. Janggun-bong via Backryong-am (hermitage), on bark, elevation about 270 m, October 13, 2013 (NIBR). Prov. Gyongsangnam, Milyang city, Danjang-myeon, Gucheon-ri, Mt. Gaji, around Pyochung Temple, on bark of Zelkova serrata, elevation about 165 m, September 8, 2009, K.H. Moon 11321 (NIBR); Hadong-gun, Hwagae-myeon, Daeseongri, Mt. Jiri, en route from Daeseong strem area to Seseok hut, on bark, elevation about 1100 m, August 10, 2006, K.H. Moon 9005 (NIBR). Prov. Jeonllanam, Gohunggun, Podu-myeon, Mt. Cheoungeung-san, St. Gumtapgil, around Geumtap temple, on bark of Zelkova serrata, elevation about 100 m, October 18, 2013, K.H. Moon 13870 (NIBR). Prov. Jeju (=Prov. Cheju), Jeju city, Jocheon-eup, Seonheul-ri, around South entrance area, on bark of Cornus controversa, elevation about $100 \mathrm{~m}$, May 24, 2012, K.H. Moon 13003 (NIBR); Jeju city (=Cheju-shi), Odung-dong, Kwanum temple, on bark of Castanea crenata, elevation about 580 m, May 29, 2001, K.H. Moon 5947 (TNS).

Type specimens examined. Japan, Honshu, Prov. Musashi (Metropolice of Tokyo), Inokashira, June 23, 1924, Y. Asahina 23a as Parmelia fraudans ssp. subfraudans Zahlbr. (holotype in W; isotype in TNS!). Japan, Honshu, Prov. Suruga, Hakone, Mt. Higane, October 15, 1922 , S. Yamashita (hb. Y. Asahina 17) as Parmelia leucutyliza f. rugulosa Asahina (lectotype in TNS!). Japan, Honshu, Prov. Suruga, Kadoike, August 17, 1929, Y. Asahina s. n. (lecotype in TNS!).

Myelochroa metarevoluta (Asahina) Elix \& Hale, Mycotaxon 29: 241, 1987.

Basinonym: Parmelia metarevoluta Asahina, J. Jpn. Bot. 35: 97, 1960. Type collection. Japan. Honshu. Prov. Shinano: Azusayama, Minamisaku-gun. On rocks; elevation about 1400 m, August 8, 1959, M. Nuno \& S. Kurokawa 59243 (lectotype in TNS! and isolectotype in US).

Parmelina metarevoluta (Asahina) Hale, Phytologia 32: 483, 1974.

Chemistry. Atranorin, galbinic acid, zeorin, leucotylin and its derivatives, and secalonic acid A.

This species is considered the sorediate morph of $M$. galbina and is known from eastern Asia and eastern North America (Hale, 1976). It is very easily distinguished from the other sorediate species by the $\mathrm{P}+$ deep yellow color reaction in the medulla from production of galbinic acid.

All the five specimens of this species in NIBR produce leucotylin only and never produce leucotylic acid, as in the case for Japanese materials (Kurokawa and Arakawa, 1997).

Myelochroa metarevoluta has been reported from China, Japan and the eastern United States (Hale, 1976). According to Jayalal et al. (2012), it was recently reported from India and Nepal. In Korea, it has been collected once on Mt. Sorak by Moon (1999) and is apparently a very rare species. This report is second record for this species in Korea. 
Specimens examined. Prov. Gangwon (=Prov. Kangwon), Inje-gun, Buk-myeon, Yongdae-ri, Mt. Sorak, around Paektam temple, on bark of Quercus sp., elevation about 460-550 m, October 6, 1995, K.H. Moon 396 $\&$ H. Kashiwadani (TNS, NIBR); Inje-gun, Buk-myeon, Yongdae-ri, Mt. Sorak, along the Backdam valley, on bark of Quercus sp., elevation about 480 m, July 10, 2005, K.H. Moon 8512 (NIBR); elevation about 460-550 m, October 6, 1995, K.H. Moon 396 \& H. Kashiwadani; Inje-gun, Buk-myeon, Yongdae-ri, Mt. Sorak, along the Backdam valley, on Acer sp., elevation about $470 \mathrm{~m}$, April 17, 2008, K.H. Moon 10227 (NIBR). Incheon, Ongjin-gun, Bukdo-myeon, Jangbong-ri, on rocks, elevation about 10 m, April 20, 2013, K.H. Moon 13205 (NIBR). Prov. Gyeongsangbuk, Gyeongju city, Jinhyeon-dong, Mt. Toham, around Seokguram Grotto, on bark of Zelkova serrata, October 15, 2013, K.H. Moon 13834 (NIBR).

Myelochroa perisidians (Nyl.) Elix \& Hale, Mycotaxon 29: 241, 1987.

Basinonym: Parmelia perisidians Nyl., Acta Soc. Sci. Fenn. 26: 6, 1900. Type collection. Ceylon, Rampodde, E. Almquist s. n. (lectotype in S! and isolectotype in $\mathrm{H}$ !).

Parmelia subsulphurata Asahina, J. Jpn. Bot. 26: 228, 1951. Type collection. Japan, Prov. Mino, Kamo-gun, Higashishirakawa-mura, August 1936, M. Yasue s. n. (lectotype in TNS!).

Myelochroa indica auct. non (Hale) Hale \& Elix: Park YS, 1990 and Jayalal et al., 2012.

For other synonyms, see Hale (1976) and Kurokawa and Arakawa (1997).

Chemistry. Atranorin, zeorin, leucotylin and and its derivatives, and secalonic acid $\mathrm{A}$.

Myelochroa perisidians resembles $M$. indica because they both have isidiate thalli; however, it can be distinguished from the latter by the loosely adnate thallus with wider lobes (0.5-2.0 mm wide) and the presence of secalonic acid A; the latter species has a hardly adnate thallus with smaller lobes (0.8-1.2 mm wide). Although the medulla of M. perisidians varies from pale yellow to almost white, that of $M$. indica is constantly white. Therefore, the final decision to distinguish between the two species should be a check for the presence or absence of secalonic acid A in the medulla.

This species was reported from Korea under $M$. indica by Park (1990) and Jayalal et al. (2012); however, Park (1990) reported that the specimens contain secalonic acid A and have lobes of 1-3 mm wide. Therefore, the specimens should be identified with $M$. perisidians rather than $M$. indica. We re-examined all materials treated under $M$. indica by Jayalal et al. and confirmed that all specimens contain atranorin, zeorin, leucotylin and secalonic acid A, characteristic chemical features for M. perisidians.
This species is widely distributed in Asia, having been recorded from India, Sri Lanka, Thailand, Japan (Hale, 1976; Kurokawa and Arakawa, 1997) and Korea. The reports from Korea were made by several authors as Parmelia subsulphurata Asahina (Kim, 1965; 1980; Kim, 1983; Ri, 1988), as $P$. perisidians Nyl. (Lee, 1987), as $M$. perisidians (Jayalal et al., 2012) and as M. indica (Park, 1990; Jayalal et al., 2012). The distribution in Korea is restricted to the southern part of the Korean peninsula, where it grows both on tree trunks and on rocks.

Specimens examined. Prov. Gyonggy (=Prov. Kyonggi), Seoul, June 1901, U. Faurie 4746 (KYO 00030581). Prov. Chungcheongnam, Mt. Jogae, on bark, elevation 310 m, January 31, 2004, J.S. Hur 040017 (KoLRI no. 007681, as M. indica). Prov. Gyeongsangbuk, Cheongsong-gun, Budong-myeon, Sangui-ri, Mt. Juwang, en route from Daegeon temple to Mt. Janggun-bong via Backrung-am (hermitage), on rock with mosses, elevation about 270 m, October 13, 2013, K.H. Moon 13786 (NIBR); same locality, on rocks, K.H. Moon 13814 (NIBR). Prov. Gyongsangnam, Sancheong-gun, Mt. Ungseobong, on bark, elevation $587 \mathrm{~m}$, October 16, 2007, J.S. Hur 070847 (KoLRI no. 007681, as M. indica). Prov. Jeonllanam, Mt. Duryun, Daeheung temple, on rock, June 8, 2003, J.S. Hur 030310 (KoLRI no. 000248, as M. indica); Gohung-gun, Sorokdo, on rock, elevation $15 \mathrm{~m}$, March 23, 2003, J.S. Hur 030067 (KoLRI no. 000043, as $M$. indica); Gohung-gun, Podu-myeon, Mt. Cheoundeung, around Geumtap temple, on bark of Zelkova serrata, elevation about $100 \mathrm{~m}$, October 18, 2013, K.H. Moon 13863 and 13874 (NIBR); Gohung-gun, Podumyeon, Namseong-ri, Mt. Mabok, en route from Maboksa temple to summit area, on bark, elevation about 200 m, October 18, 2013, K.H. Moon 10948 (NIBR).

\section{Key to the species of Korean Myelochroa}

1. Thallus isidiate …... M. perisidians (Nyl.) Elix \& Hale

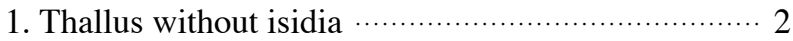

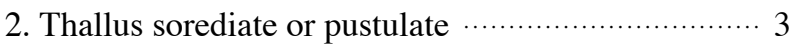

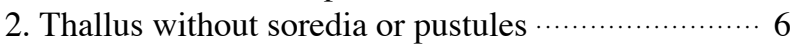

3. Pustules never forming soredia ……..................... 4

3. Pustules turning into soredia; soredia farinose …..... 5

4. Medulla $\mathrm{P}+$ brick red, containing galbinic acid; moniliform cells present in the medulla

M. hayachinensis (Kurok.) Elix \& Hale

4. Medulla $\mathrm{P}-$, lacking galbinic acid; moniliform cells absent in the medulla

M. leucotyliza $(\mathrm{Nyl}$.) Elix \& Hale

5. Medulla $\mathrm{P}+$ brick red, containing galbinic acid; moniliform cells present in the medulla M. metarevoluta (Asahina) Elix \& Hale

5. Medulla $\mathrm{P}-$, lacking galbinic acid; moniliform cells 
absent in the medulla

M. aurulenta (Tuck.) Elix \& Hale

6. Upper surface distinctly rugose, often bursting open along the ridges of wrinkles; upper cortex fragile and easily flaking away, exposing medulla

M. entotheiochroa (Hue) Elix \& Hale

6. Upper surface smooth, cortex almost entire …...... 7

7. Thallus rather tightly adnate; medulla $\mathrm{P}+$ brick red, containing galbinic acid; moniliform cells present in the medulla .............. M. galbina (Ach.) Elix \& Hale

7. Thallus adnate; medulla $\mathrm{P}-$ or $\mathrm{P}+$ yellow, lacking galbinic acid; moniliform cells absent in the medulla . M. irrugans (Nyl.) Elix \& Hale

\section{ACKNOWLEDGEMENTS}

We wish to express our sincere the curators of DUKE, KoLRI, TNS and US for permitting us to examine specimens of Myelochroa. Moon thanks Dr. Y. Ohmura, curator of TNS, for his kind support during her stay in TNS. Thanks are extended to Dr. A. Aptroot (ABL Herbarium, Soest) for the identification of a parasitic fungus, Marchandiomyces corallines. We'd like to thank Prof. S.Y Yoon, Baekseok University, Cheonan city, Korea for her corrections of our English manuscript. This work was supported by a grant to Moon from the National Institute of Biological Resources (NIBR No. 2013-01-039, 201401105, 2013-01-007 and 2014-07101 ) funded by the Ministry of Environment (MOE) of the Republic of Korea.

\section{REFERENCES}

Acharius, E. 1814. Synopsis methodica lichenum, sistens omnes hujus ordinis naturalis detectas plantas, quas, secundum genera, species et varietates disposuit, characteribus et differentiis emendatis definivit, nec non synonymis et observationibus selectis illustravit auctor. Lund. 392 pp.

Asahina, A. 1951. Lichenes Japoniae novae vel minus cognitae. (4). J. Jpn. Bot. 26:225-228.

Asahina, A. 1952. Lichens of Japan. Vol. II. Genus Parmelia. Research Intstitue for Natural Resources Shinjuku, Tokyo. 162 pp. +23 pl.

Asahina, A. 1960. Lichenologische Notizen (160-163). J. Jpn. Bot. 35:97-102.

Ban, J.W. 1983. Taxonomical study of lichens in the National Park Mt. Deoyu area. Thesis of Master Degree, Jeonbug National University. 35 pp. +8 pl.

Cho, S.S. and Y.N. Lee. 1980. Studies on Parmeliae in Mt. Deokyoo Area. Kor. J. Mycol. 8:149-157.

Culberson, C.F. 1972. Improved conditions and new data for the identification of lichen products by a standardized thin-layer chromatographic method. Jour. Chromatogr. 72:113-125.

Elix, J.A. and M.E. Hale. 1987. Canomaculina, Myelochroa, Parmelinella, Parmelinopsis and Parmotremopsis, five new genera in the Parmeliaceae (lichenized Ascomycotina). Mycotaxon 29:233-244.

Elix, J.A. 2001. Additional lichen records from Australia 46. Parmeliaceae. Australasian Lichenology 48:27-33.

Hale, M.E. Jr. 1974. Bulbothrix, Parmelina, Relicina and Xanthoparmelia, four new genera in the Parmeliaceae. Phytologia 28:479-490.

Hale, M.E. Jr. 1976. A monograph of the lichen genus Parmelina Hale (Parmeliaceae). Smithsonian Contrib. Bot. 33:1-60.

Hue, A.M. 1899. Lichenes extra-europaei a pluribus collectoribus ad Museum Parisiensi missi. - Nouv. Archiv. du Muséum d'Histoire Naturelle de Paris. Nouv. Arch. Mus. hist. nat. Paris 1:27-220.

Huneck, S., J.D. Ri, T. Ahti and J. Poelt. 1989. Zur Kenntnis der Flechtenflora von Korea. Herzogia 8:177-185.

Huneck S., H.T. Lumbsch and I. Yoshimura. 1994. Contribution to the lichen flora of the Diamond Mountains (Korea). J. Hattori Bot. Lab. 75:365-369.

Hur, J.S., H. Harada, S.O. Oh, K.M. Lim, E.S. Kang, S.M. Lee, H.Y. Kahng, H.W. Kim, J.S. Jung and Y.J. Koh. 2004. Distribution of Lichen Flora on South Korea. J. Microbiol. 42:163-167.

Jayalal, U., S. Joshi, S.O. Oh, Y.J. Ko and J.S. Hur. 2012. A taxonomic study of the genus Myelochroa in South Korea. Mycobiology 40:217-224.

Kashiwadani, H., K.H. Moon, M. Inoue, G. Thor and Y.S. Kim. 2002. Lichens of the Cheju Island, Republic of Korea. Proceedings of the 3rd and 4th Symposium on Collection building and Natural Histroy Studies in Asia and the Pacific Rim. Ntl. Sci. Mus., Tokyo. pp. 115-135.

Kim, K.S. 1983. Taxonomical Studies on Lichens in the National Park Mt. Naejang Area. Thesis of Master's Degree, Jeonbug National University. 27 pp. +7 pl.

Kim, S.H. 1965. Studies on the lichens in Korea. (II). Enumeration of genus Parmelia in Korea. Bull. Kongju Teachers Col. 2:72-80.

Kim, S.H. 1979. Studies on the lichens in Korea (V). Bull. Kongju Teachers Col. 15:259-268.

Kim, S.H. 1980. The vertical distribution of the lichens on Mt. Han-ra. Chehu island. Bull. Kongju Teachers Col. 16:241-279.

Kim, S.H. 1981. Floral studies on the lichens in Korea. Bull. Kongju Teachers Col. 17:279-304.

Kurokawa, S. 1964. Lichens. 39 pp. National Science Museum, Tokyo (in Japanese).

Kurokawa, S. 1968. New or noteworthy species of Parmelia of Japan. J. Jpn. Bot. 42:349-353.

Kurokawa, S. 1972. Probable mode of differentiation of lichens in Japan and eastern North America. In: Graham, 
A. (ed.): Floristic and Paleofloristics of Asia and Eastern North America. pp. 139-146.

Kurokawa, S. and S. Arakawa. 1997. Revision of Japanese species of Myelochroa (Parmeliaceae). Bull. Bot. Gard., Toyama 2:23-43.

Lee, D.Y. 1987. A taxonomic study of genus Parmelia (lichens) in Mt. Chiri. Thesis of Master's Degree, Jeonbug National University. 48 pp.

Moon, K.H. 1997. Corticolous macrolichens around Woljong Temple, Mt. Ohdae, Korea. Journal of Natural Sciences, Sookmyung Women's University 8:65-70.

Moon, K.H. 1998. Mt. Pukhan National Park Forest ecosystem impact assessment and measures for the establishment of urban pollution-lichens. Korea National Park Service. pp. 115-126.

Moon, K.H. 1999. Lichens of Mt. Sorak in Korea. J. Hattori Bot. Lab. 86:187-220.

Moon, K.H., S. Kurokawa and H. Kashiwadani. 2000. A list of Thailand species of Parmelia (sens. lat.) preserved in TNS. Natn. Sci. Mus., Tokyo, Monographs 18:97-106.

Moon, K.H., H. Kashiwadani and K. Kobayashi. 2013. A New Species of Myelochroa (Parmeliaceae, Lecanorales) from Shiga Prefecture, Japan. J. Jpn. Bot. 88:140-143.

Nylander, W. 1885. Parmeliae exoticae novae. Flora 68:605615.

Nylander, W. 1890. Lichenes Japoniae. Accedunt observationibus lichenes insulae Labuan. Paris. 122 pp.
Nylander, W. 1900. Lichenes Ceylonenses et Additamentum ad Lichenes Japoniae. Acta Soc. Sci. Fennicae 26:1-33.

Park, S.T. 1976. Taxonomical studies on the family Parmeliaceae on Jeonbuk in Korea. Bull. Educ. Jeonbuk. Univ. 2:77-86.

Park, S.T. 1979. Ecological study on the distribution of Parmeliaceae in Mt. Hanla. Bull. Educ. Jeonbuk. Univ. 5: 47-52.

Park, Y.S. 1990. The macrolichen flora of South Korea. Bryologist 93:105-160.

Ri, J.D. 1988. Spore plants of Korea. 7. Lichens. Comprehensive Encyclopedia of Science Publishing. Pyongyang. 279 pp. (in Korean).

Ri, J.D. 2000. Useful resources and species composition of lichens in Mt. Duryu-san. Biology, North Korea. 3:49-52.

Ri, J.D. and J.G. Hyun. 1988. A lichens list of Mt. Gwanmobong, Korea. Biology, North Korea. pp. 42-47.

Tuckerman, E. 1858. Supplement to an enumeration of North American lichens; Part first, containing brief diagnoses of new species. Amer. Jour. Sci. and Arts 25:422-430.

Yazici, K., J.A. Elix and A. Aslan. 2010. Some parmelioid lichens new to Turkey and Asia. - Mycotaxon 111:489494. 